\title{
Investigation of Antioxidative Properties of Multifunctional Additives of Alkyl Phenolate Type and Development of New Lubricant Compositions
}

\author{
Yulduz Beyuk Aga Ramazanova \\ Institute of Chemistry of Additives after Acad. A.M. Guliev of ANAS, Baku, Azerbaijan \\ Email: pishnamazzadeh@mail.ru
}

How to cite this paper: Ramazanova, Y.B.A. (2019) Investigation of Antioxidative Properties of Multifunctional Additives of Alkyl Phenolate Type and Development of New Lubricant Compositions. Open Journal of Yangtze Gas and Oil, 4, 225-230. https://doi.org/10.4236/ojogas.2019.43017

Received: June 12, 2018

Accepted: July 22, 2019

Published: July 25, 2019

Copyright $\odot 2019$ by author(s) and Scientific Research Publishing Inc. This work is licensed under the Creative Commons Attribution International License (CC BY 4.0).

http://creativecommons.org/licenses/by/4.0/

\begin{abstract}
The results of studies of the antioxidant properties of multifunctional alkylphenolate type additives indicate the calcium salts of condensation products of alkylphenols $\left(\mathrm{C}_{8}-\mathrm{C}_{12}\right)$ with formaldehyde and the following amines: aminoacetic acid, benzotriazole, diethanolamine and boric acid, as well as their carbonated compounds. The determination of the antioxidant properties of the additives is tested on the AПCM-1M apparatus. New lubricant compositions for diesel internal combustion engines oil meeting the required standards for these oils have been developed. The study of additives, which possess simultaneously detergent-dispersing, neutralizing, antioxidant anti-wear properties, revealed the dependence of antioxidant properties on their alkalinity.
\end{abstract}

\section{Keywords}

Additives, Oxidation, Lubricant Composition

\section{Introduction}

As is known, when developing motor oils intended for operation in diesel internal combustion engines, special attention is paid to the correct selection of the multifunctional additives that make up the composition as well as the physicochemical parameters of the base oils used. In this case, the synergism effect is achieved, which is that the total effect of the additive mixture is greater than the effect of each of them separately [1]-[6]. 


\section{The Determination of the Antioxidant Properties of the Additives to Be Tested on the АПСМ-1M Apparatus (Method ВТИ GOST 981-75)}

Among the additives used in the compositions an important place is occupied by antioxidant additives of phenolic type, it can be used for possibly creating new motor oils with improved antioxidant properties. Therefore, the purpose of the study is to investigate the stability of such additives-derivatives of alkylphenols containing active elements in their structures-heteroatoms (nitrogen, sulfur, boron) and metal (calcium) and identify among them the most effective methods for developing new lubricant compositions, combining them with additives of other types. \{Therefore, the goal is set to investigate the stability of such additives-alkyl phenol derivatives containing the active elements-heteroatoms (nitrogen, sulfur, boron) and metal (calcium) in their structures, identifying among them the most effective methods to develop new low-ash lubricating compositions by combining them with additives of other types.\} The use of calcium-containing additives in place of the traditional barium-containing additives is not only to increased ash content of the latter, but also to environmental problems associated with the emission of nanoparticles of harmful barium compounds together with the exhaust gases of the ICE. It should be noted that the high ash content of additives has a negative effect on the efficiency of exhaust gas purification systems, which are equipped with internal combustion engines that meet the requirements of Euro-4 and Euro-5 [7]. In this regard, a new direction is developing oils with low or $\{$ no zero content of sulfate ash, phosphorus and sulfur both at home and abroad (Zow and Zero SAPS) [8] [9] [10] [11] [12].

The additives used in the work have high washing-dispersing properties, as evidenced by the values of their alkaline numbers-93.6 - $132 \mathrm{mg} \mathrm{KOH} / \mathrm{g}$. Alkali numbers of carbonated versions of these additives are ranged from $130.0-154.0$ $\mathrm{mg}(\mathrm{KOH}) / \mathrm{g}$. Additives include active elements of $\mathrm{Ca}(2.4 \%-5.0 \%), \mathrm{N}(0.4 \%-$ $1.4 \%), \mathrm{S}(1.6 \%-1.9 \%), \mathrm{B}(0.3 \%-0.4 \%)$.

To determine the dependence of the effect of the action on the structure of the test additives, their number is calculated from the need to develop a sample with an alkaline value of $5.5-6.0 \mathrm{mg}(\mathrm{KOH}) / \mathrm{g}$ (Table 1$)$.

Table 1. The characteristics of alkyl phenolate additives.

\begin{tabular}{|c|c|c|c|c|c|c|}
\hline \multirow{2}{*}{ № } & \multirow{2}{*}{ Additives } & \multirow{2}{*}{$\begin{array}{c}\text { Alkaline } \\
\text { number/ } \\
\left.\mathrm{mg}(\mathrm{KOH}) \cdot \mathrm{g}^{-1}\right)\end{array}$} & \multicolumn{4}{|c|}{ Content $/ \%$} \\
\hline & & & $\mathrm{Ca}$ & $\mathrm{N}$ & $\mathrm{S}$ & B \\
\hline A. & $\begin{array}{l}\text { Calcium salt of condensation product } \\
\qquad\left(\mathrm{C}_{8}-\mathrm{C}_{12}\right) \text { alkylphenol with } \\
\text { formaldehyde and aminoacetic acid }\end{array}$ & 108.6 & 2.4 & 0.75 & - & - \\
\hline B. & -benzotriazole & 93.6 & 2.5 & 1.4 & 2.3 & - \\
\hline C. & -diethanolamine and boron acid & 132.0 & 2.6 & 0.62 & - & 0.44 \\
\hline $\mathrm{A}_{1}$. & -carbonated & 130.0 & 4.8 & 0.5 & - & - \\
\hline $\mathrm{B}_{1}$. & -carbonated & 154.0 & $4.9-5.0$ & 1.2 & 1.6 & - \\
\hline $\mathrm{C}_{1}$. & -carbonated & 148.7 & 5.1 & 0.38 & - & 0.31 \\
\hline
\end{tabular}

${ }^{*} \mathrm{~A}_{1}, \mathrm{~B}_{1}, \mathrm{C}_{1}$-carbonated versions of additives $\mathrm{A}, \mathrm{B}, \mathrm{C}$. 
To determine the antioxidant properties of the additives investigated, laboratory tests are performed on the АПСМ-1M apparatus (ВТИ GOST 981-75 method) by exposure to oxygen at an elevated temperature in the presence of a catalyst (Figure 1).

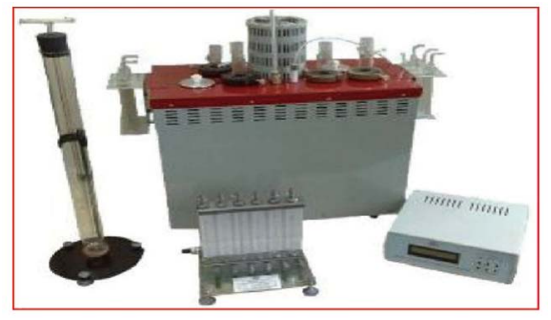

Figure 1. The apparatus АПСМ-1M.

Based on ВТИ GOST 981-75 method, the tests are carried out at $120^{\circ} \mathrm{C}$ for 14 $\mathrm{h}$, and then the tests are performed in more severe conditions-at $120^{\circ} \mathrm{C}$ for $30 \mathrm{~h}$ and at $140^{\circ} \mathrm{C}$ for $40 \mathrm{~h}$.

The estimated indicators of the process are the acid number of oxidized oil, the amount of sediment formed in it, and the content of volatile low-molecular acids.

According to GOST 981-75, tests are carried out at $120^{\circ} \mathrm{C}$ for $14 \mathrm{~h}$, and then the tests are performed in more severe conditions-at $120^{\circ} \mathrm{C}, 140^{\circ} \mathrm{C}$ for 30 and 40 h, respectively, as shown in Figure 2 and Figure 3.

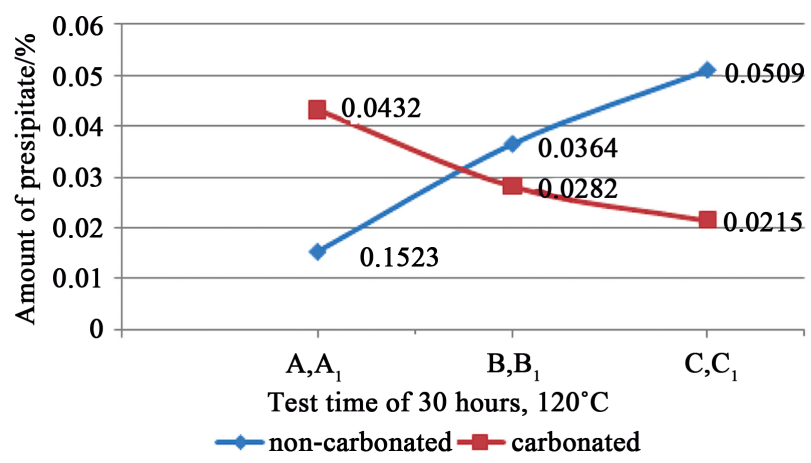

Figure 2. The amount of sediment formed during the test period.

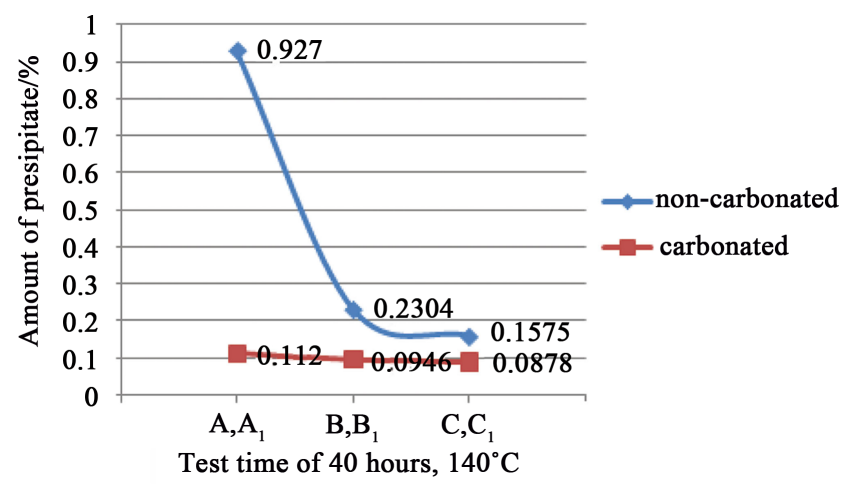

Figure 3. The amount of sediment formed during the test period. 
The estimated indicators of the process are the acid number of oxidized oil, the content of volatile low-molecular acids and the amount of sediment formed in it.

The content of the precipitate in the oxidized oil $(X)$ in percent is calculated by the formula:

$$
X=\frac{m_{1} \cdot 100}{m}
$$

where $m$-is the mass of oxidized oil, $g ; m_{1}$-sediment mass, $g$.

The results of the studies show that the investigated detergent-precipitating additives, being multifunctional, can sufficiently improve the antioxidant stability of the oils.

During oxidation of M-8 base oil (for 30 and $40 \mathrm{~h}$ at temperatures of $120^{\circ} \mathrm{C}$ and $140^{\circ} \mathrm{C}$ ), the amount of precipitate formed is $1.122 \%$ and $2.042 \%$, and at compound $(A)$ is used (calcium salt of the condensation product of alkylphenol with formaldehyde and amino acetic acid), the precipitate is $0.152 \%$ and $0.927 \%$, respectively.

This is the reason for a sharp decrease in the acid number of oxidized oil and volatile low molecular weight acids.

The tests reveal that high efficiency of carbonated additives is obtained.

Taking into account the high detergent-dispersing and, at the same time, antioxidant properties of additives, as well as a simple method for their preparation, engine oils of the $Б \Pi, B_{2}$, and $\Gamma_{2}$ groups are created with their participation.

\section{Results and Its Discussion}

For the test results, the arithmetic mean of two parallel determinations is taken. Table 1 shows the results of testing M-8 oil samples with additives and without additives.

As can be seen from the results of the comparative studies (Table 2), all the tested calcium-containing additives improve the properties of M-8 against oxidation, as evidenced by low amounts of precipitated oil in M-8 oil at 30 (Figure 2) and $40 \mathrm{~h}$ (Figure 3), as well as low acid values and volatile low-molecular acids of oxidized oil samples. As for the stable M-8 control oil, the test results, for $30 \mathrm{~h}$ at $120^{\circ} \mathrm{C}$ and $140^{\circ} \mathrm{C}$, indicate its low stability against oxidation under these conditions, the precipitate is $1.122 \%$ and $2.042 \%$, the acid value of the oxidized oil is 3.520 and $4.2833 \mathrm{mg}(\mathrm{KOH}) / \mathrm{g}$ respectively. The acid number of low molecular weight volatile acids formed as a result of oxidation is 1.6771 and 2.3146 $\mathrm{mg}(\mathrm{KOH}) / \mathrm{g}$ respectively.

Considering the high antioxidant properties of additives synthesized in a simple way, non-carbonated additives $(\mathrm{A})$ and $(\mathrm{B})$ and carbonated $\left(\mathrm{B}_{1}\right)$ and with them based on M-8, MC-20 and a number of industrial additives, detergent-surfactant, anti-wear and other effects, including foreign additives Viscoplex-2-600, Viscoplex-4-550 and Viscoplex-5-309 (Evonik company, Germany), MİXOIL-3103 lubricant compositions have been developed. 
Table 2. The results of tests of additives in oil M-8.

\begin{tabular}{|c|c|c|c|c|c|c|c|c|}
\hline \multirow{4}{*}{\multicolumn{2}{|c|}{ Tested sample }} & \multirow{4}{*}{$\begin{array}{c}\text { Concentration/ } \\
\%\end{array}$} & \multicolumn{6}{|c|}{ Test conditions } \\
\hline & & & \multirow{2}{*}{\multicolumn{2}{|c|}{$\begin{array}{c}\text { Precipitation } \\
\text { in oxidized oil/\% }\end{array}$}} & \multicolumn{4}{|c|}{ Acid number/(mg $\left.(\mathrm{KOH}) \cdot \mathrm{g}^{-1}\right)$} \\
\hline & & & & & \multicolumn{2}{|c|}{ Of oxidized oil } & \multicolumn{2}{|c|}{ Of volatile low-molecular acids } \\
\hline & & & $\begin{array}{l}120^{\circ} \mathrm{C} \\
30 \text { hour }\end{array}$ & $\begin{array}{l}140^{\circ} \mathrm{C} \text {, } \\
40 \text { hour }\end{array}$ & $\begin{array}{l}120^{\circ} \mathrm{C}, \\
30 \text { hour }\end{array}$ & $\begin{array}{l}140^{\circ} \mathrm{C} \text {, } \\
40 \text { hour }\end{array}$ & $\begin{array}{l}120^{\circ} \mathrm{C}, \\
30 \text { hour }\end{array}$ & $\begin{array}{l}140^{\circ} \mathrm{C} \\
40 \text { hour }\end{array}$ \\
\hline \multicolumn{2}{|c|}{ Oil M-8 } & - & 1.1220 & 2.0427 & 3.5200 & 4.2833 & 1.6771 & 2.3146 \\
\hline A & AKİ-140 & 5.7 & 0.01523 & 0.9270 & 0.1660 & 0.8800 & 0.0050 & 0.0071 \\
\hline $\mathrm{B}$ & AKİ-209 & 6.3 & 0.0364 & 0.2304 & 0.3520 & 0.5280 & 0.0052 & 0.0086 \\
\hline $\mathrm{C}$ & AKİ-210 & 4.9 & 0.0509 & 0.1575 & 0.9620 & 0.1575 & 0.0012 & 0.0054 \\
\hline $\mathrm{A}_{1}$ & AKİ-150 & 4.3 & 0.0432 & 0.1120 & 0.3280 & 0.9200 & 0.0041 & 0.0053 \\
\hline $\mathrm{B}_{1}$ & AKİ-218 & 3.9 & 0.0282 & 0.0946 & 0.2610 & 0.0884 & 0.0033 & 0.0114 \\
\hline $\mathrm{C}_{1}$ & AKİ-219 & 4.0 & 0.0215 & 0.0878 & 0.7140 & 0.9860 & 0.0047 & 0.0104 \\
\hline
\end{tabular}

Lubricant composition with additive AKİ-218 allows to create engine oil M-20БП, based on the additive AKİ-150 oil grade $M-14 \Gamma_{2}$, and with the additive AKİ-210 engine oil grade $\mathrm{M}-10 \mathrm{~B}_{2}$ meeting the required standards of ИПО (GOST 11063) for these oils.

The physicochemical parameters of the newly formulated compositions and the results of the studies are given in Table 3.

Table 3. The characteristics of new lubricant oils compositions.

\begin{tabular}{|c|c|c|c|c|c|c|c|c|}
\hline \multirow[b]{2}{*}{$\begin{array}{c}\text { Package } \\
\text { of additives }\end{array}$} & \multirow[b]{2}{*}{$\begin{array}{c}\text { Kinematic } \\
\text { viscosity at } \\
100^{\circ} \mathrm{C} /\left(\mathrm{mm}^{2} \cdot \mathrm{s}^{-1}\right)\end{array}$} & \multirow[b]{2}{*}{$\begin{array}{l}\text { Viscosity } \\
\text { index/1 }\end{array}$} & \multirow[b]{2}{*}{$\begin{array}{c}\text { Alkaline } \\
\text { number/ } \\
\left(\mathrm{mg}(\mathrm{KOH}) \cdot \mathrm{g}^{-1}\right)\end{array}$} & \multirow[b]{2}{*}{$\begin{array}{c}\text { Corrosion } \\
\mathrm{n} \text { lead } /\left(\mathrm{g} \cdot \mathrm{m}^{-2}\right)\end{array}$} & \multirow[b]{2}{*}{$\begin{array}{l}\text { Ash } \\
\text { content/\% }\end{array}$} & \multicolumn{3}{|c|}{ ИПО stability } \\
\hline & & & & & & $\begin{array}{c}\text { Kinematic } \\
\text { viscosity after } \\
\text { oxidation at } \\
100^{\circ} \mathrm{C} /\left(\mathrm{mm}^{2} \cdot \mathrm{s}^{-1}\right)\end{array}$ & $\begin{array}{l}\text { The amount } \\
\text { of sludge in the } \\
\text { oxidized oil/\% }\end{array}$ & $\begin{array}{c}\text { Viscosity } \\
\text { increase at } \\
50^{\circ} \mathrm{C} / \%\end{array}$ \\
\hline $\begin{array}{c}\text { MC-20 1.1\%AKİ-218 } \\
1.5 \% \text { MX-3103 } \\
0.35 \% \text { C-400 } \\
0.003 \% \text { ПМС-200 A }\end{array}$ & 21.02 & 87 & 3.2 & none & 0.72 & 22.47 & 0.33 (40 hour) & 39.8 \\
\hline $\begin{array}{c}\mathrm{M}-8 \\
4.0 \% \text { AKİ-150 } \\
1.5 \% \text { C- } 150 \\
0.8 \% \text { A- } 22\end{array}$ & 14.25 & 90 & 7.8 & none & 1.43 & 16.54 & 0.45 (50 hour) & 34.53 \\
\hline $\begin{array}{c}2.4 \% \text { Viscoplex-4-550 } \\
0.5 \% \text { Viscoplex-5-309 } \\
0.003 \% \text { ПМС-200A }\end{array}$ & & & & & & & & \\
\hline $\begin{array}{c}\text { М-8 } \\
\text { 3.3\% AКİ-210 } \\
1.0 \% \text { C-150 } \\
1.0 \% \text { ДФ-11 }\end{array}$ & 11.36 & 90 & 5.8 & none & 0.66 & 14.12 & 0.38 (40 hour) & 46.21 \\
\hline $\begin{array}{c}1.1 \% \text { Viscoplex-2-600 } \\
0.3 \% \text { Viscoplex-5-309 } \\
0.003 \% \text { ПМС-200A }\end{array}$ & & & & & & & & \\
\hline
\end{tabular}

\section{Conclusions}

The multifunctional alkyl phenolate additives AKİ-218, AKİ-150 and AKİ-210 are investigated, their antioxidant properties are revealed and new lubricant compositions are created by using them. The composition with AKİ-218 addi- 
tive allows creating $\mathrm{M}-20 Б \Pi$ engine oil, with AKİ-150 additive- $\mathrm{M}-14 \Gamma_{2}$ oil, and with AKİ-210 additive-M-10B $\mathrm{B}_{2}$ engine oil meeting the required standards for these oils.

\{Thus, the investigated alkyl phenolate additives, being multifunctional, also possess antioxidant properties, and the new lubricating compositions created with them meet the required standards for engine oils of БП groups (ТУ 38 101593), $\Gamma_{2}$ (GOST 8581), $B_{2}$ (GOST 12337) by combining phenolic type with known additives. $\}$

\section{Conflicts of Interest}

The author declares no conflicts of interest regarding the publication of this paper.

\section{References}

[1] Selezneva, I.E., Levin, A.Ya. and Monin, S.V. (1999) Detergent-Dispersant Additives for Motor Oils. Alkylphenolates. Chemistry and Technology of Fuels and Oils, 35, 389-395. https://doi.org/10.1007/BF02694105

[2] Guliev, A.M. (1985) Technology of Additives to Oils and Fuels. L. Chemistry, 312.

[3] Mukhin, A.A., Kashchitskaya, V.Yu. and Potanova, S.A. (2009) On the Advisability of Using a Mixture of Phenolic and Amine Antioxidants in Mineral Oils. ChTFO, No. 3, 45 .

[4] Zolotov, A.V., Kuzmina, G.N., Zolotov, V.A., et al. (2013) A Composition of Organic Hetero Compounds as an Antioxidant and Antiwear Additive for Mineral Lubricating Oils. Petroleum Chemistry, 53, 262-266. https://doi.org/10.1134/S0965544113040142

[5] Djavadova, A.A., Yusifova, A.R., Ramazanova, Y.B. and Nagiyeva, E.A. (2014) Research of Protective Properties of Detergent-Dispersant Alkilphenolyate Type Additives. Refinery and Petrochemistry, No. 9, 46-49.

[6] Mamedova, A.Kh., Kazimzadeh, A.K. and Nagiyeva, E.A. (2011) New Modifications of Alkylphenolyate Additives to Motor Oils Containing Nitrogen and Sulfur. Oil Industry of Azerbaijan, No. 8, 62-65.

[7] Zolotov, A.V., Parenago, O.P., Bartko, R.V., Kuzmina, G.N., Zolotov, V.A. and Sipatrov, A.G. (2013) Composition of Hetero-Organic Compounds as Antioxidant and Antiwear Additive to Mineral Lubricating Oils. Petrochemistry, 53, 297-301. https://doi.org/10.1134/s0965544113040142

[8] Chudinovskikh, A.L. (2015) Chemmotological Principle of Evaluating Deposit Forming Tendency of Automotive Motor Oils. Chemistry and Technology of Fuels and Oils, 51, 231-235. https://doi.org/10.1007/s10553-015-0596-7

[9] Trofimova, G.L., Ivanova, O.V. and Evstafiev, V.P. (2014) The Study of the Interaction of Additives to Motor Oils When Creating Packages and Compositions. ChTFO, No. 6, 9-11.

[10] Djavadova, A.A., Farzaliyev, V.M., Ramazanova, Yu.B. and Azimov, E.V. (2008) Motor Oils for High Powered Automative Diezels. Patent of Azerbaijan İ 20080202.

[11] Javadova, A.A., Ramazanova, Yu.B. and Mammadova, A.Kh. (2016) Motor Oil for High-Speed, Autotractor and Stationary Diesel Engines. Patent of Azerbaijan İ 2016 0120.

[12] Javadova, A.A., Farzaliev, V.M. and Ramazanova, Yu.B. (2015) Engine Oil for Marine Diesel Engines. Patent of Azerbaijan İ 20150075. 